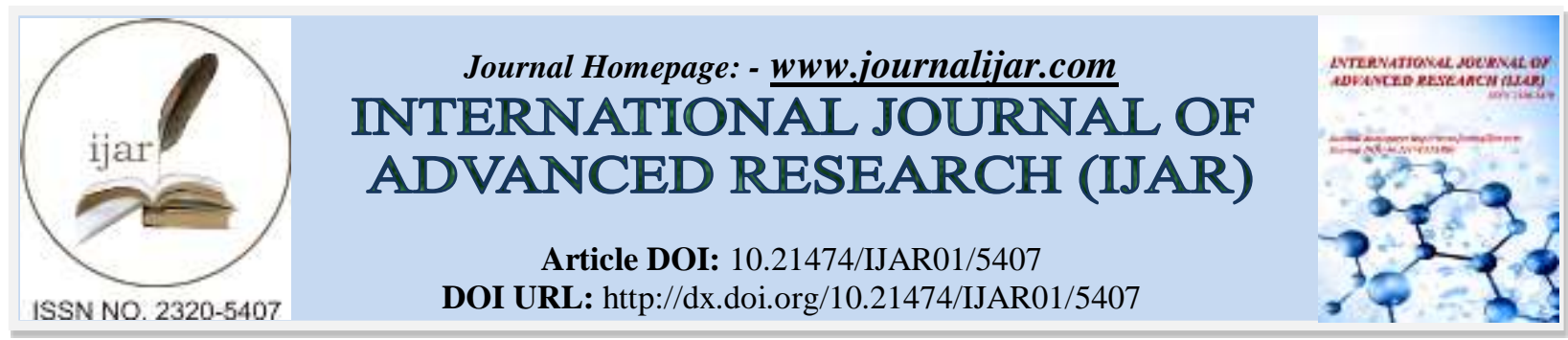

RESEARCH ARTICLE

\title{
THE EFFECT OF PRODUCT AWARENESS AND PERCEIVED QUALITY TOWARDS PURCHASE INTENTION THROUGH PERCEIVED RISK AND TRUST ON CUSTOMERS OF INDOMARET AND ALFAMART IN SURABAYA.
}

Hananiel M. Gunawan and Yolanda Soedibyo. Universitas Pelita Harapan Surabaya.

\section{Manuscript Info}

Manuscript History

Received: 12 July 2017

Final Accepted: 14 August 2017

Published: September 2017

Key words:-

Purchase Intention.
Paid Plastic Bags, Green Marketing,

\begin{abstract}
Currently, the Government of Indonesia has started to execute several policies in order to give more protection the environment. One of them is by regulating the policy of paid plastic bags which started since February 21, 2016, the same day where the National Trash Care Day was established. Along with the paid plastic bag policy, it will encourage customers to switch to shopping bags that can be repeatedly used and environmentally friendly. One of the efforts that can be done by the Indonesian retail industry is by offering environmentally friendly shopping bags at their sores. The study will develop the concept of green marketing in government policy that seeks to change the consumption patterns of Indonesian people to use plastic bags that are harmful to the environment.

This research will use the quantitative approach by using multiple regressions through SPSS 16 software. The sample of this research is 300 respondents residing in Surabaya with non-probability sampling technique. Sampling method used in this research is purposive sampling. After collecting the data and data processing, all hypothesis are accepted.
\end{abstract}

Copy Right, IJAR, 2017,. All rights reserved.

\section{Introduction:-}

In the last two decades, human consciousness has experienced a dramatic shift across the globe (Barber, 2010). This is marked by the increasing number of people who realize that environmental problems are complex and becoming important issues to be resolved. This awareness emerges as a result of the concerning climate change in the world that is felt by humans around the world. The problem that often happens is among many people who are aware and care about the environment, but there are still many people who are aware and concern but do not put any action. This incident was also supported by the opinion of Picket and Ozaki (2008) who stated that people who are environmentally conscious do not always behave pro-environmental. Therefore, the application of green marketing, as a form of change as the "new" society concerns has not been implemented properly.

In Indonesia, one of the ways to motivate the community to protect the environment together was the designation of the National Trash Care Day on February 21, 2016 (Tribunnews.com, March 17, 2016). On that occasion, Indonesia's retail industry charges Rp. 200 for each plastic bags for the customer. This provision concerning the paid plastic bag is described in the letter of Directorate General of Waste Management, Waste, and Hazardous Toxic Substances from the Ministry of Environment and Forestry Number: S.1230 / PSLB3-PS / 2016 on price and 
mechanism of application of paid plastic bags. One of the causes of this policy needs to be applied into effect as it is based on Jambeck et al (2015), Indonesia is second in the world as the most plastic user country.

Along with a paid plastic bag policy, it will encourage customers to switch to shopping bags that can be repeatedly used and environmentally friendly. One of the businesses that can be done by the Indonesian retail industry is by offering environmentally friendly shopping bags at their sales outlets. This offer is expected to further support customers to make purchases and switch from the use of plastic bags to more eco-friendly shopping bags. Ecofriendly shopping bags that are still relatively new, require education from the company so that the green products can be accepted by the society. Companies can educate customers through marketing communications mix consisting of advertising, direct marketing, and personal selling with respect to the "green" benefits offered (Kotler and Keller, 2012).

This research will use customers of Indomaret and Alfamart convenient store as the research object. Alfamart and Indomaret are the leading business actors in retail industry in Indonesia. These two retailers generally sell a variety of food products, beverages, and a number of other customer's daily necessities. Currently, Alfamart shares with Alfa trademark and it is owned by PT. Sumber Alfaria Trijaya. Meanwhile, Indomaret is one of the subsidiaries of Salim Group managed by PT. Indomarco Prismatama.

\section{Literature Review:-}

Product Awareness sheth and Sisodia (2012) explain that awareness is the level of conscious of potential customers about the information provided by the seller regarding the products offered. Before customers can buy a product, they must know and understand the product first. Instinctively, customers should have a connection with the company's offering, and only realizing the existence of the product would not be enough. This awareness can occur related to the understanding and knowledge possessed by the customer through the education provided by the company. Corporate education can be done through marketing communications mix consisting of advertising, direct marketing, and personal selling. Ultimately, the customers' awareness would enable them to make them feel familiar with the products, brands, and the reasons why they are offereded the eco-friendly shopping bags. In this case, Sheth and Sisodia (2012) state that awareness is the extent to which customers can obtain information about the characteristics of the product or offer.

\section{$\mathrm{H}_{1}$ : Product Awareness has a negative effect on Perceived Risk of environmentally friendly bag consumer.}

\section{Perceived Quality:-}

Customers expecting better quality than before, so quality is a strong competitive weapon (Parasuraman et al., 1985). Perceived quality has attracted interest from practitioners and researchers because of the belief that the effect of perceived quality favorable to marketing performance (Sweeney et al, 1999). Since customer ratings are usually based on incomplete or asymmetric information, customers can trust products based on the perceived quality of a product or brand. (Kardes et al., 2004). Perceived quality is a set of attributes related to the perception of brand or product quality, perceived quality can build a positive word of mouth effect, reduce customer management costs, increase purchases, and increase premium prices (Qualls and Rosa 1995, Sweeney et al, 1999). When companies launch their new products in a misleading "green" claims, confusing and exaggerating the environmental issues of their products, customers are becoming reluctant to trust their products (Kalafatis and Pollard, 1999). As a result, perceived quality plays a more important role in the current environmental era.

\section{$\mathrm{H}_{2}$ : Perceived Quality has a positive effect on Perceived Quality of environmentally friendly bag consumer}

\section{Perceived Risk:-}

Peter and Ryan (1976), Stone and Grønhaug (1993), and Aaker (1996) stated that perceived risk is a concern of potential customers based on discrepancy between the actual product and what the seller promised. Therefore, perceived risk has three important aspects, which indicate who is at risk, for what kind of risk, and when it occurs. Raymond A Baeur (1960) was the first person to spark the idea of perceived risk in customer behavior research (Stone and Grønhaug, 1993). Raymond's idea has generated several speculations and inspired the research area. Stone and Winter (1985) suggest that perceived risk is a subjective expectation of loss.

\section{$\mathrm{H}_{3}$ : Perceived Risk has a negative effect on Trust of environmentally friendly bag consumer}

\section{Trust:-}

Trust is defined as the potential consumers' trust for the reliability and integrity of the product and the seller (Moorman et al., 1993). When a potential consumer has a belief in a company's product offering, it means that the 
potential consumer believes that a product or service provider can be counted on to behave in such a way that the long-term interests of the customer will be served (Crosby et al., 1990). This trust will make the potential consumers willing to depend on a person, or something, in a particular situation with no doubt or concern (McKnight and Chervany, 2001).

\section{$\mathrm{H}_{4}$ : Trust has a positive effect on purchase intention of environmentally friendly bag consumer}

\section{Purchase Intention:-}

Purchase intention can be defined as the probable level of potential customers to buy a particular brand designated for themselves after a specific evaluation (Khan et al., 2012). Halim and Hameed (2005) describe customers' purchase intention as possible prospects who have plans to purchase products in the future, make repeat purchases, and searching for more information regarding the related products. Jin and Kang (2011) describe purchase intention linked to four customer behaviors including unquestionable plans to buy products, think decisively to buy products, contemplate to buy products in the future, and to buy specific products

\section{Research Issue and Methodology:-}

In this study the target of population were customers who never bought and used any environmentally friendly bag from Indomaret and Alfamart. They were also not aware of any information about environmentally friendly bag from Indomaret and Alfamart (through catalog, visit the stores, and through other medias). The characteristics of the respondent are as follow: men and women, residing in Surabaya, adults with the ability to make decisions. This research uses primary data and it is obtained from the distribution of questionnaires to the respondents in accordance with the characteristics of populations. Questionnaire distribution was conducted in Indomaret and Alfamart at Surabaya. From 310 questionnaires distributed, 300 questionnaires were returned and valid to be used for data formulation.

From the questionnaire completed by respondents, the indicators to measure were derived from previous researches. For product awareness, perceived quality, perceived risk, trust, and purchase intention from research by Wang and Tsai (2014); Chen and Chang (2013); and Chen and Chang (2012. There were 15 indicators for 5 variables tested, and these can be seen from the following research model:

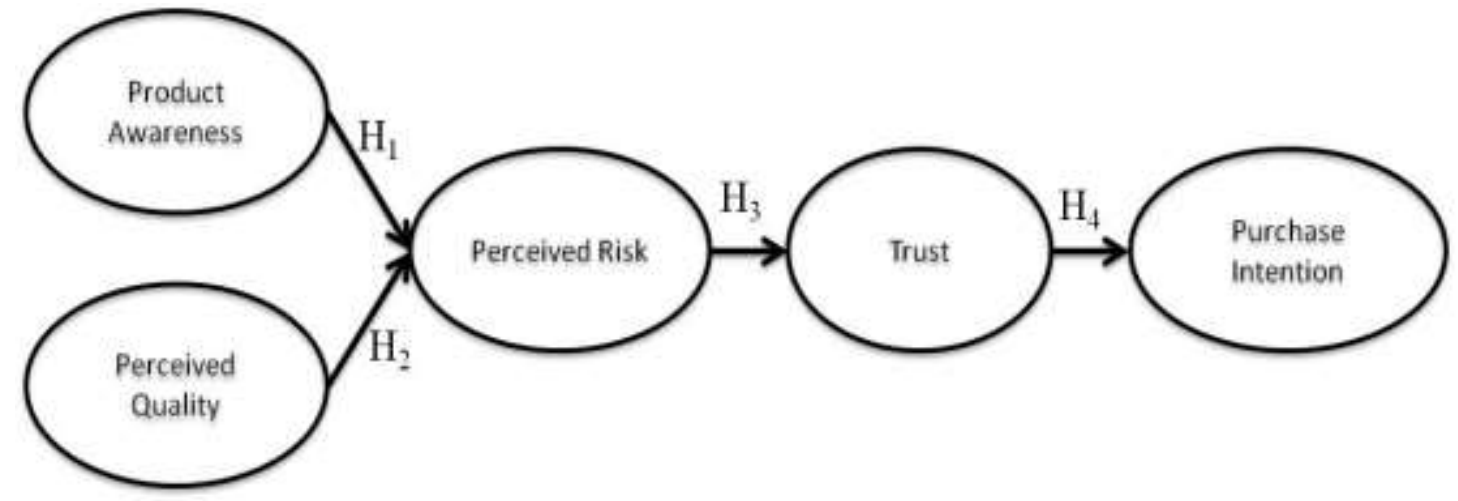

Figure 1:-Research Model.

Source: Analysis, 2017

Areas that were used within this research were interval level measurement. Type of scale used was Likert scale, a statement that has a range from $1=$ disagree to $5=$ agree, the scale represents the respondents opinion for the questions regarding the objects being studied. In which the highest the score or number selected indicated the higher of ratings, and vice versa.

\section{Findings and Discussion:-}

\section{Findings:-}

This study is using multiple regressions to examine the effect between the independent variables towards the dependent variable. Statistical analysis tool used to answer the problem formulation of this research is SPSS 16 software. When all primary data has been collected, then the statistical testing can be done.

The respondent was made up of $28.7 \%$ men and $71.3 \%$ women. Almost $61 \%$ of the group is under the age of 40 . 
Validity Test:-

Table 1:-Validity Test.

\begin{tabular}{|l|l|l|}
\hline Indicator & Factor Loading & Note \\
\hline Product Awareness: & & \\
\hline PA1 & .353 & Valid \\
\hline PA2 & .366 & Valid \\
\hline PA3 & .224 & Valid \\
\hline Perceived Quality: & & \\
\hline PQ1 & .230 & Valid \\
\hline PQ2 & .251 & Valid \\
\hline PQ3 & .176 & Valid \\
\hline Perceived Risk: & & \\
\hline PR1 & .305 & Valid \\
\hline PR2 & .296 & Valid \\
\hline PR3 & .319 & Valid \\
\hline Trust: & & \\
\hline TR1 & .211 & Valid \\
\hline TR2 & .290 & Valid \\
\hline TR3 & .352 & Valid \\
\hline Purchase Intention: & & \\
\hline PI1 & .383 & Valid \\
\hline PI2 & .411 & Valid \\
\hline PI3 & .372 & Valid \\
\hline Soure: SPSS rut & \\
\hline
\end{tabular}

Source: SPPS 16 result, 2017

The criteria of validity test is if the value of the Corrected Item-Total Correlation for $n=300$ is higher than 0.138 ( $r$ table), however, if the value of the factor loading is less than the 0.138 , then the statement is considered invalid or failed. Based on the test of the data validity, it is proven that all indicators used to estimate each variable is valid, since the value of the factor loading for every items are more than 0.197 .

\section{Reliability Test:-}

Reliability test is done by comparing cronbach's alpha value, if the value is higher than 0.6 , then the statement is considered reliable.

Table 2:-Reliability Test.

\begin{tabular}{|l|l|l|}
\hline Variable & Cronbach's Alpha Based on Standardized Items & Note \\
\hline Product Awareness & 0.795 & Reliable \\
\hline Perceived Quality & 0.775 & Reliable \\
\hline Perceived Risk & 0.688 & Reliable \\
\hline Trust & 0.757 & Reliable \\
\hline Purchase Intention & 0.679 & \\
\hline
\end{tabular}

Source: SPPS 16 result, 2017

From the table 2, it is proven that the variables of overall brand image, perceived risk, perceived quality, and purchase intention all resulting the value of Cronbach alpha higher than 0.60. So, it can be concluded that the statements developed the variables can be said to be reliable and can be used for further analysis.

\section{Normality Test:-}

The result from SPSS output is used to see the normality of the Active Cooperation data with macroeconomic variables using a graph as seen in Figure 2. 


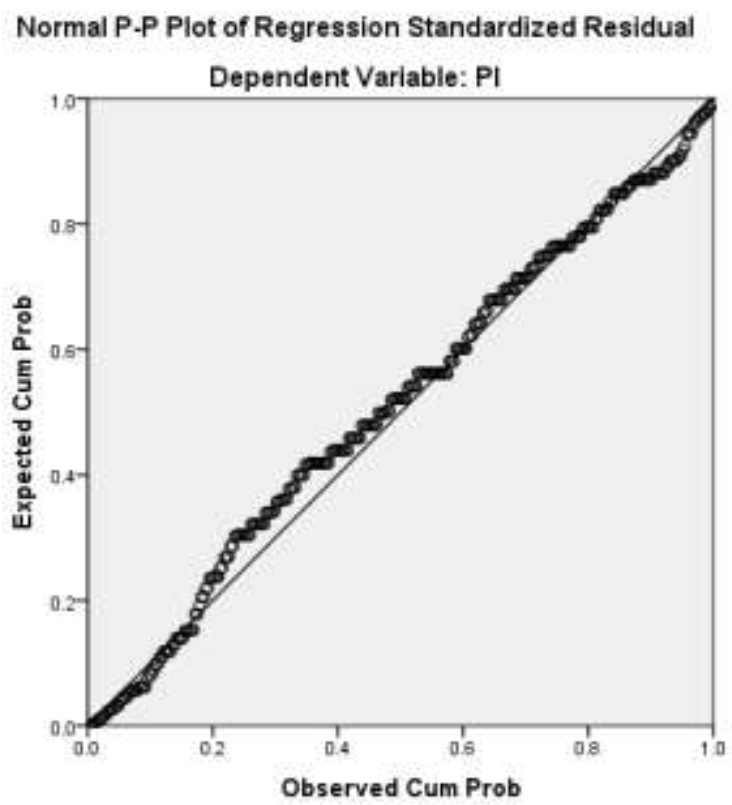

Source: SPPS 16 result, 2017

Figure 2:- Normality Test (P-Plot).

From the normality test result, data that used in the study are normally distributed. The explanation is because the spread of the data were not far from the diagonal line so it can be considered to pass the normality test. Therefore, this research can be continued.

Results of Coefficient Determination:-

Table 3:-The results of coefficient determination are as follows:

\begin{tabular}{|l|l|l|l|}
\hline Model & $\mathrm{R}$ & $\mathrm{R}$ Square & Adjusted R Square \\
\hline 1 & $.482^{\mathrm{a}}$ & .232 & .229 \\
\hline \multicolumn{2}{|l}{} \\
\hline \multicolumn{2}{|l|}{ a. Predictors: (Constant), TR } \\
\hline \multicolumn{2}{l}{ bependent Variable: PI }
\end{tabular}

Source: SPPS 16 result, 2017

From table 3, coefficient determination/R-square $\left(\mathrm{R}^{2}\right)$ value generated is as much as 0.23 which means that the variations of variables together can explain the variation of variable overall PI by $23 \%$, while the rest explained for other variables beyond the model which is not yet observed.

\section{Result of Multiple Regressions:-}

The results of multiple regressions are as follows:

Table 4:-Multiple Regressions.

\begin{tabular}{|l|l|l|}
\hline \multicolumn{2}{|l|}{ Model } & Standardized Coefficients \\
\cline { 2 - 3 } \multicolumn{2}{l|}{1} & Beta \\
\hline & TR & \\
\hline
\end{tabular}

Source: SPPS 16 result, 2017

From table 4, the regression equation can be written as follows:-

$$
\begin{gathered}
\text { PI }=\text { b1TR } \\
\mathrm{PI}=0.482 \mathrm{TR}
\end{gathered}
$$

Based on table 4, all independents variables have positively influence towards PI. Furthermore, Trust has the greatest regression coefficient compare to other variables, which is 0.482 . 


\section{F-test:-}

The results of F-test are as follows:

Table 5:-F-test.

\begin{tabular}{|l|l|l|l|l|l|l|}
\hline \multicolumn{2}{|l|}{ ANOVA $^{\mathbf{b}}$ Model } & Sum of Squares & df & Mean Square & F & Sig. \\
\hline \multirow{4}{*}{1} & Regression & 22.688 & 1 & 22.688 & 89.953 & $.000^{\text {b }}$ \\
\cline { 2 - 7 } & Residual & 75.163 & 298 & .252 & & \\
\cline { 2 - 7 } & Total & 97.852 & 299 & & & \\
\hline \multicolumn{2}{|l|}{ a. Dependent Variable: PI } & & & & \\
\hline \multicolumn{2}{|l|}{ b. Predictors: (Constant), TR } & & & \\
\end{tabular}

Source: SPPS 16 result, 2017

Based on the calculation of SPSS from table 5, the significance of F test value in the model is 0.000 , this mean $\mathrm{H} 0$ is rejected, so it can be concluded that independent variables together influencing PI significantly.

\subsection{7 t-test}

The results of t-test are as follows:

Table 8:-t-test For Multiple Regression.

\begin{tabular}{|l|l|l|l|l|}
\hline \multicolumn{2}{|l|}{ Model } & \multicolumn{1}{l|}{ Sig. } \\
\hline \multirow{2}{*}{1} & (Constant) & 1.912 & .057 \\
\cline { 2 - 5 } & TR & .538 & .241 \\
\hline \multicolumn{2}{|l|}{} & \\
\hline
\end{tabular}

Source: SPSS 16.00 result, 2016

From table 8, it can be explained that the variables Trust have significant effect towards Purchase Intention because it has a significance value below 0.05 .

\section{Discussion:-}

From the research that has been done, the result is from four hypotheses proposed, all hypothesis are supported. The first hypothesis, which state "Product Awareness has a negative effect on Perceived Risk of environmentally friendly bag consumer" is accepted. The reason is because the regression coefficient is 0.113 with t-test value of 0.047, which is below 0.05 . This shows a consistent result with the previous study conducted by Chen and Chang (2012).

The second hypothesis, which states, "Perceived Quality has a positive effect on Perceived Quality of environmentally friendly bag consumer" is supported. The reason is because the regression coefficient is 0.427 with t-test value of 0.000 , which is below 0.05 . This shows an consistent result with the previous study conducted by Chen and Chang (2012).

The third hypothesis, which states, "Perceived Risk has a negative effect on Trust of environmentally friendly bag consumer" is supported. The reason is because the regression coefficient is 0.502 with t-test value of 0.000 , which is below 0.05. This shows a consistent result with the previous study conducted by Chen and Chang (2013).

The fourth hypothesis, which states, "Trust has a positive effect on purchase intention of environmentally friendly bag consumer" is supported. The reason is because the regression coefficient is 0.482 with t-test value of 0.000 , which is below 0.05 . This shows a consistent result with the previous study conducted by Chen and Chang (2012).

\section{Conclusion, Limitation and Research Extension:- Conclusion:-}

From the research that has been done, the result is from four hypotheses proposed, all hypothesis are supported. Trust is a variable that affects the Purchase Intention the most, because the higher level of the consumer's trust about 
product the higher the consumer wants to buy and try the product. The reason is because a potential customer's trust is a determinant of long-term customer behavior (Lee et al., 2011). Therefore, the intention to buy a potential customer will be influenced by the trust of prospective customers (Harris and Goode, 2010). The previous literatures also state that customer trust is the determinant of customer purchase intentions (Schlosser et al., 2006). More specifically, purchase intentions require customers' trust (McCole and Plamer, 2001) because trust increases customer confidence that sellers are not tied in with an opportunistic behavior (Gefen, 2000).

All these times, the Indonesian people trust regarding the environmentally friendly shopping bags offered by Indomaret and Alfamaret still less due to consumer awareness of the shopping bag is still minimal. This lack of awareness is due to the absence of any definite determination by the government in reducing the use of plastic-made shopping bags that can damage the environment. Uncertain determination is also accompanied by the lack of Indomaret and Alfamart's agility in offering environmentally friendly shopping bags. This makes consumers do not feel the urgent need of environmentally friendly shopping bags. This low trust can also occur due to a lack of consumer understanding of the eco-friendly shopping bags' quality. Consumers often think that eco-friendly shopping bags are low quality bags. The notion that eco-friendly shopping bags are of low quality is because consumers receive little information and reviews about eco-friendly shopping bags. Low understanding finally raises doubts from within the consumer to the products offered.

With a high awareness and a good understanding of consumers of the quality offered by environmentally friendly shopping bags by Indomaret and Alfamart, then, consumers' doubt on eco-friendly shopping bags will be gone. This can happen because consumers are convinced that when the eco-friendly shopping bags offered have been purchased then consumers will not feel disappointed with the poor quality provided. Perceived risk is the only variable that enables consumer confidence to be higher. When consumers do not have doubts about the eco-friendly shopping bags, their confidence will be developed and finally, they will be able to make purchases of the eco-friendly shopping bags.

\section{Limitations and Research Extension:-}

There are several limitations within this research. This research is only using limited sample in Surabaya. It also can be concluded that researchers and strategists need to consider other issues relating to product awareness, perceived quality, perceived risk, and trust to increase purchase intention. In further research, it is expected to increase the sample used in order for the data to be more generalized.

\section{References:-}

1. Aaker, D.A. (1996). Building Strong Brands. New York: The Free Press.

2. Barber, N., Taylor, C. \& Strick, S. (2009), Wine consumers environmental knowledge and attitudes: influence on willingness to purchase. International Journal of Wine Research, 1(1), 59-72.

3. Chen, Yu-Shan., \& Chang, Ching-Hsun. (2012). The Influences of Green Perceived Quality and Green Brand Awareness on Green Brand Equity: The Mediation Effect of Green Perceived Risk. Proceedings of PICMET '12: Technology Management for Emerging Technologies

4. Chen, Yu-Shan., \& Chang, Ching-Hsun. (2012). Enhance green purchase Intentions: The roles of green perceived value, green perceived risk, and green trust. Emerald Group Publishing Limited, 50(3), 502-520.

5. Chen, Yu-Shan., \& Chang, Ching-Hsun. (2013). Towards green trust: The influences of green perceived quality, green perceived risk, and green satisfaction. Emerald Group Publishing Limited, 51(3),63-82.

6. Crosby, L. A., Evans, K.R. \& Cowles, D. (1990). Relationship Quality in Services Selling: An Inter- personal Influence Perspective. Journal of Marketing, 54(3), 68-81.

7. Gefen, D. (2000). E-Commerce: The Role of Familiarity and Trust. OMEGA: The International Journal of Management Science, 28(6), 725-737.

8. Halim, W.Z.W. \& Hamed, A.B. (2005). Consumer purchase Intention at traditional restaurant and fast food restaurant. Paper presented at ANZMAC 2005 Conference: Consumer Behavior.

9. Harris, L.C. \& Goode, M.M.H. (2010). Online services capes, trust, and purchase intentions. Journal of Services Marketing, 24(3), 230-243.

10. Jambect, et al. (2015). Worst Plastic Waste offenders Named. heraldscotland.com.

11. Jin, B. \& Kang, J.H. (2011). Purchase intention of Chinese consumers toward a US apparel brand: a test of a composite behavior intention model. Journal of Consumer Marketing, 28(3), 187-199.

12. Kalafatis, S.P., \& Pollard, M. (1999). Green marketing and Ajzen's theory of planned behaviour: a cross-market examination. Journal of Consumer Marketing, 16(4/5), 441-460. 
13. Kardes, F.R., Posavac, S.S., \& Cronley, M.L. (2004). Consumer inference: a review of processes, bases, and judgment contexts. Journal of Consumer Psychology. 14(3), 230-256.

14. Khan, I., Ghauri, T. A., \& Majeed, S. (2012). Impact of Brand Related Attributes on Purchase Intention of Customers, a Study about the Customers of Punjab, Pakistan. Interdisciplinary journal of contemporary research in business, 4(3), 194-200

15. Kotler, P.T., \& Keller, K.L. (2012). Marketing Management (14 ${ }^{\text {th }}$ ed). New Jersey: Prentice Hall

16. Lee, J., Park, D-H. \& Han, I. (2011). The different effects of online consumer reviews on consumers' purchase intentions depending on trust in online shopping malls: an advertising perspective, Internet Research, 21(2), 187-206.

17. McKnight, D. H. \& Chervany, N. L. (2001). Trust and Distrust Definitions" One Bite at a Time. LNAI 2246, 27-54

18. McCole, P. \& A. Palmer. (2001), A Critical Evaluation of the Role of Trust in Direct Marketing over the Internet. Paper presented at World Marketing Congress, University of Cardiff, Wales.

19. Moorman, C., Deshpande, R. \& Zaltman, G. (1993). Factors affecting trust in market relationships. Journal of Marketing. 57(1), 81-101

20. Parasuraman, A., V. A. Zeithaml., \& L. L. Berry. (1985). A conceptual model of service quality and its implications for future research. Journal of Marketing, 49(4), 41-50.

21. Peter, J. P. \& Ryan, M. J. (1976). An investigation of perceived risk at the brand level. Journal of Marketing Research, 13, 184-188.

22. Pickett-Baker, J. \& Ozaki, R. (2008), Pro-environmental products: marketing influence on consumer purchase decision, Journal of Consumer Marketing, 25(5), 281-293.

23. Qualls, W.J., \& Rosa, J. (1995). Assessing industrial buyers' perceptions of quality and their effects on satisfaction. Industrial Marketing Management, 24(5), 359-368.

24. Sanusi. (2016). 21 Februari, Uji Coba Kantong Berbayar. Tribunbisnis.com

25. Schlosser, A.E., White, T.B. \& Lloyd, S.M. (2006), Converting web site visitors into buyers: how web site investment increases consumer trusting beliefs and online purchase intentions. Journal of Marketing, 70(2), 133-48.

26. Sheth, J.N. \& Sisodia, R.S. (2012). The 4A's Marketing. New York and London: Routledge

27. Stone, N.R. \& Grønhaug, K. (1993). Perceived Risk: Further Considerations for the Marketing Discipline. European Journal of Marketing, 27(3), 39-50.

28. Stone, R. N. \& Winter, F. W. (1985). Risk in buyer behavior contexts: a clarification. Faculty Working Paper 1216 EWP 860505. Champaign, IL: College of Commerce and Business Administration, University of Illinois.

29. Sweeney, J. C., G. N. Soutar, \& L. W. Johnson. (1999). The role of perceived risk in the quality-value relationship: A study in a retail environment. Journal of Retailing,75(1), 77-105.

30. Wang, Ya-Hui. \& tsai, Cing-Fen. (2014). The Relationship Between Brand Image And Purchase Intention: Evidence From Award Winning Mutual Funds. The International Journal of Business and Finance Research, $8(2), 27-40$. 